\title{
Shelf life of pitaya [Stenocereus pruinosus Otto ex Pfeiff.) Buxb.] fruit affected by temperature and guar gum, beeswax, oleic acid, and thyme essential oil coatings
}

Vida de anaquel de frutos de pitaya [Stenocereus pruinosus Otto ex Pfeiff.) Buxb.] afectada por temperatura y recubrimientos de goma guar, cera de abeja, ácido oleico y aceite esencial de tomillos

\section{Leticia García-Cruz ${ }^{1}$ (D), Diana Guerra-Ramírez² (D) , María Teresa Martínez-Damián ${ }^{3}$ (D) , Holber Zuleta-Prada² (D) , Salvador Valle-Guadarrama ${ }^{1 *}$ (D)}

\author{
${ }^{1}$ Departamento de Ingeniería Agroindustrial, Universidad Autónoma Chapingo (UACh), Carr. México-Texcoco km 38.5, Chapingo, 56230, Texcoco de Mora, \\ Estado de México, México. \\ ${ }^{2}$ Laboratorio de Productos Nacionales, Departamento de Preparatoria Agrícola (UACh). \\ ${ }^{3}$ Departamento de Fitotecnia (UACh). \\ *Corresponding author: svalleg@taurus.chapingo.mx
}

Received:

October $27^{\text {th }}, 2020$

Acceptance date:

February $7^{\text {th }}, 2021$

Online publication date:

June $19^{\text {th }}, 2021$

Este es un artículo en acceso abierto que se distribuye de acuerdo a los términos de la licencia Creative Commons.

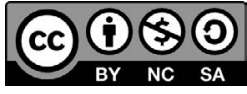

Reconocimiento-

NoComercia-

CompartirIgual 4.0

Internacional

\section{ABSTRACT}

Pitaya [Stenocereus pruinosus Otto ex Pfeiff.) Buxb.] produces fruit with high commercialization potential, but its shelf life is limited to few days. The objective of this study was to apply biopolymeric coatings to extend the shelf life of pitaya fruits at $25^{\circ} \mathrm{C}$ and under refrigeration at $12{ }^{\circ} \mathrm{C}$. The following variables were handled at each temperature: fruits without any treatment (Control), fruits coated with 1,000 ppm emulsion of thyme essential oil, and fruits coated with $1 \%$ emulsion of guar gum, $7.5 \%$ beeswax, and $7.5 \%$ oleic acid, without essential oil, and with 1,000 ppm of thyme essential oil. Shelf life was $6 \mathrm{~d}$ at $25^{\circ} \mathrm{C}$, without the beneficial effect of coatings, but increased to $15 \mathrm{~d}$ with refrigeration and coatings based on guar gum, beeswax, and oleic acid, since fungal growth was delayed, and weight loss was reduced. This allowed fresh appearance without significant modification of color, firmness, $\mathrm{pH}$, total soluble solids, titratable acidity, contents of soluble phenols and betalains, and antioxidant capacity.

\section{KEYWORDS}

Antioxidant capacity, betalains, biopolymers, postharvest quality, refrigeration, soluble

RESUMEN

La pitaya [Stenocereus pruinosus Otto ex Pfeiff.) Buxb.] produce un fruto con alto potencial de comercialización, pero con vida útil de pocos días. El objetivo del presente estudio fue aplicar recubrimientos biopoliméricos para alargar la vida de anaquel de frutos de pitaya a $25^{\circ} \mathrm{C}$ y bajo refrigeración a $12^{\circ} \mathrm{C}$. En cada temperatura se manejaron frutos sin ningún tratamiento (Control), frutos tratados con emulsión de 1,000 ppm de aceite esencial de tomillo y frutos recubiertos con emulsión de 1\% goma guar, 7.5\% cera de abeja y 7.5\% ácido oleico, sin aceite esencial y con 1,000 ppm de aceite esencial de tomillo. La vida útil fue de $6 \mathrm{~d}$ a $25^{\circ} \mathrm{C}$, sin el efecto benéfico de los recubrimientos, pero aumentó a $15 \mathrm{~d}$ con refrigeración y uso de recubrimientos de goma guar, cera de abeja y ácido oleico, pues retrasó el desarrollo fúngico y redujo la pérdida de peso, permitiendo apariencia fresca sin modificación significativa de color, firmeza, $\mathrm{pH}$, sólidos solubles totales, acidez titulable, contenido de fenoles solubles y betalaínas y capacidad antioxidante. 
PALABRAS CLAVE

Betalaínas, calidad postcosecha, capacidad antioxidante, fenoles solubles, biopolímeros, refrigeración

\section{INTRODUCTION}

Pitaya [Stenocereus pruinosus Otto ex Pfeiff.) Buxb.], a columnar cactus, develops in arid and semi-arid regions (Casas et al. 2007). Its fruit is a polyspermatic berry with red, yellow, orange, pink, purple, and white pulp. The fruit has an aromatic, juicy, and sweet pulp (Chuck-Hernández et al.2015), which is rich in minerals such as $\mathrm{Fe}, \mathrm{Cu}$, and $\mathrm{Zn}$ (García-Cruz et al. 2013), and contains high quantities of bioactive compounds, such as betalains and polyphenolic compounds (García-Cruz et al. 2017; Rodríguez-Sánchez et al. 2017).

The pitaya fruit is non-climacteric (Armella et al. 2003), so harvest must be done at consumption maturity and shelf life is commonly limited to 3-5 d due to fungal proliferation (García-Cruz et al. 2016) and the presence of thorns which perforate the fragile epicarp during packaging (Shirai et al. 2016). Rosas-Benítez et al. (2016) showed that pitaya fruits can be handled without thorns during storage. However, weight loss due to transpiration increases derived from the exposure of tissue around the areolar zones. The use of refrigeration for handling pitaya fruits in postharvest has been studied in an incipient way. Shirai et al. (2016) showed that, with refrigeration and coatings based on chitosan and neem essential oil, shelf life can be extended with better appearance, consistency, and aroma, but with flavor alteration.

Biopolymeric coatings can maintain firmness and extend the shelf life of fruits (Martínez-Mendoza et al. 2020) due to the modification of the gas exchange capacity (Torres-León et al. 2018) that causes a modified atmosphere type effect. Besides, coatings can serve as a vehicle for incorporating active agents that help reduce transpiration and prevent microorganism proliferation (Rives-Castillo et al. 2018). In other cacti fruit, biopolymeric coatings with essential oils have proven to be an effective strategy to minimize microbial development and lengthen the postharvest life (Valle-Ortiz et al. 2019). In this context, the objective was to apply biopolymeric coatings to extend the shelf life of pitaya fruits at $25^{\circ} \mathrm{C}$ and under refrigeration at $12^{\circ} \mathrm{C}$.

\section{Materials And Methods}

\section{Plant material}

Pitaya (S. pruinosus) red variant fruits (Figure 1) were used. Fruits were harvested at Dolores Hidalgo, Huitziltepec, Puebla, Mexico (18 51' 06' N, 97 55' $00^{\prime \prime} \mathrm{W} ; 1920$ masl). The physiological condition corresponded to commercial maturity, characterized by an easy detachment of thorns and brightness in epicarp. Fruits were placed at $12{ }^{\circ} \mathrm{C}$ for $24 \mathrm{~h}$ previous to the experiment. Those with mechanical damage and diseases or pest were eliminated.
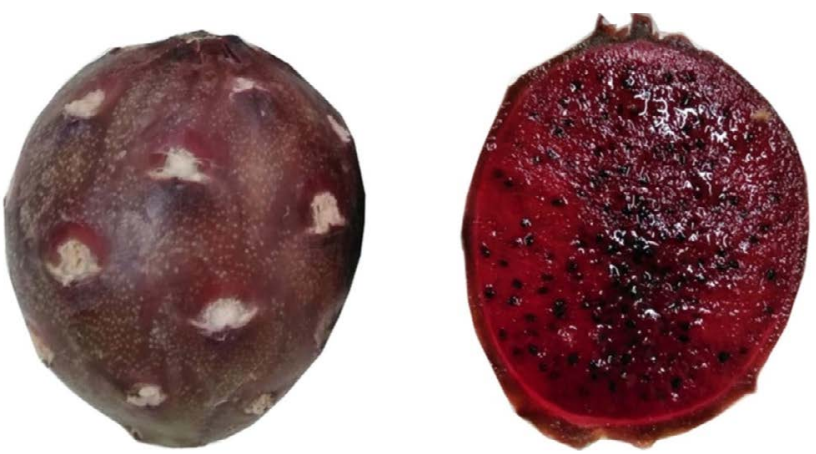

Figure. 1. External (left) and internal (right) appearance of red variant pitaya (Stenocereus pruinosus) fruits without thorns.

\section{Experimental organization}

Fruits were handled at $25{ }^{\circ} \mathrm{C}$ and $75 \%$ relative humidity (Rh), and with $12{ }^{\circ} \mathrm{C}$ and $90 \%$ Rh. Four treatments were formed at each storage condition: untreated fruit (Control), fruits immersed for $10 \mathrm{~s}$ in a 1,000 ppm emulsion of thyme essential oil (Eo), fruits coated with a $1 \%$ guar gum and $15 \%$ lipid component (Gg) emulsion, and fruits coated with an emulsion of $1 \%$ guar gum, 15\% lipid phase, and 1,000 ppm thyme essential oil (Gg+Eo). The lipid phase included beeswax and oleic acid at a 50:50 ratio (Table 1). After application, fruits were exposed to ambient air until dryness on the surface. Batches of four fruits were packed in organza cloth and placed together at the 
respective condition to allow fruits to interact among them. The experiment installation day was numbered as zero. Four fruits of each treatment were retired on days zero, $1,2,3,4,5$, and 6 from the $25^{\circ} \mathrm{C}$ conditions. Also, they were retired on days zero, 2, 4, 6, 8, 10,12, and 14 from 12 ${ }^{\circ} \mathrm{C}$ storage to evaluate appearance, weight loss, epicarp and pulp color and firmness, $\mathrm{pH}$, titratable acidity, antioxidant activity, and contents of total soluble solids, betalains, and total soluble phenols.

\section{RESPONSE VARIABLES}

\section{Cumulative weight loss}

Fruits were weighed at the beginning of the experiment and after their removal from storage with a digital scale (Ohaus, USA; $0.01 \mathrm{~g}$ resolution). Based on initial data, cumulative weight loss was determined in percentage.

\section{Appearance}

The appearance was evaluated with a panel of five untrained judges through a categorical scale of five points, where 5 was excellent, and 1 was appalling.

\section{Color attributes}

Color was measured in the fruit epicarp and mesocarp with a Hunter Lab colorimeter (Mini Scan XE Plus 45/0-L, USA) expressed as lightness $\left(\mathrm{L}^{*}\right)$, hue angle $\left(\mathrm{H}^{*}\right)$, and chroma (Sant'Anna et al. 2013).

\section{Firmness}

A texture analyzer (TAxT2i, Stable Micro Systems, UK) was used. A needle probe was used to assess epicarp firmness, with a compression routine at $1 \mathrm{~mm}$ s1 speed until deformation of $2 \mathrm{~mm}$ was achieved. Similarly, a 5-mm diameter spherical probe was used to evaluate mesocarp firmness at $1 \mathrm{~mm} \mathrm{~s} 1$ until a $5 \mathrm{~mm}$ deformation was achieved.

\section{Total soluble solids}

An Abbe refractometer (Atago Co. Ltd., model 211-W10, Japan) was used to determine total soluble solids (TSS, \%) from a drop of juice.

\section{$\mathrm{pH}$ and titratable acidity}

A liquid obtained through maceration of $5 \mathrm{~g}$ of pulp with $35 \mathrm{~mL}$ of distilled water was used to measure $\mathrm{pH}$ with a portable potentiometer (Hanna Instruments, model HI-8420, Italy), and titratable acidity with $\mathrm{NaOH} 0.01 \mathrm{~N}$ and phenolphthalein as indicator.

\section{Betalains content}

Betalains content was evaluated in $1 \mathrm{~g}$ of pulp mixed with $10 \mathrm{~mL}$ of $80 \%$ methanol. Samples were sonicated for $15 \mathrm{~min}$ in a Branson ${ }^{\circledR}$ bath (model 1800, USA), agitated in darkness for $30 \mathrm{~min}$ at room temperature, and centrifuged at $2200 \times \mathrm{g}$ for $10 \mathrm{~min}$ (Hettich zentrifugen; Universal Mod. 32, Germany). The residue was submitted to a second similar treatment. The supernatants were pooled and evaluated in terms of absorbance with a UV-vis spectrophotometer with a microplates reader (Synergy ${ }^{\circledR} 2$ Microplate reader, Gen5 software, Biotek Instruments Inc., Winoosky, VT USA). The betacyanin and betaxanthin contents were determined as described by Castellanos-Santiago and Yahia (2008) with the calculation: $\mathrm{B}(\mathrm{mg} / \mathrm{kg})=(\mathrm{A} \times \mathrm{DF} \times \mathrm{MW} \times \mathrm{V}) /(\varepsilon \times \mathrm{m} \times \mathrm{L})$, where $\mathrm{B}$ is betacyanins or betaxanthins, $\mathrm{A}$ is the absorbance at $538 \mathrm{~nm}$ for betacyanins and $487 \mathrm{~nm}$ for betaxanthins, DF is dilution factor, MW is molecular weight (betanine $=550 \mathrm{~g} \mathrm{~mol}^{1}$ and indicaxanthine $=308 \mathrm{~g} \mathrm{~mol}^{1}$ ), $\varepsilon$ is the molar extinction coefficient (betanine $=6.0 \times 10^{6}$ $\mathrm{L} \mathrm{mol}^{1} \mathrm{~cm}^{1}$ and indicaxanthine $\left.=4.8 \times 10^{6} \mathrm{~L} \mathrm{~mol}^{1} \mathrm{~cm}^{1}\right), \mathrm{m}$ is mass of sample $(\mathrm{kg})$, and $\mathrm{L}$ is the cell length $(0.5 \mathrm{~cm})$.

\section{Total soluble phenols content}

The total soluble phenols (TSP) content was determined in the same extract of betalains, with the Folin-Ciocalteu (FC) reagent method (Singleton and Rossi 1965), adapted to a Synergy ${ }^{\circledR}$ spectrophotometer (Biotek Instruments Inc., Winoosky, VT USA) with a microplates reader. Twenty-five microliters of extract were mixed with 20 $\mu \mathrm{L}$ of the FC $0.2 \mathrm{~N}$ reagent; then $125 \mu \mathrm{L}$ of distilled water and $30 \mu \mathrm{L}$ of $20 \%(\mathrm{v} / \mathrm{v})$ sodium carbonate $\left(\mathrm{Na}_{2} \mathrm{CO}_{3}\right)$ were added. Samples were left in darkness for $30 \mathrm{~min}$ at room temperature, absorbance was measured at $760 \mathrm{~nm}$, and TSP were determined based on a gallic acid curve $\left(\mathrm{R}^{2}=0.995\right)$ and expressed in $\mathrm{mg}$ gallic acid equivalents per kilogram of fresh sample $\left(\mathrm{mg} \mathrm{kg}^{1}\right)$. 


\section{Antioxidant capacity by ABTS and FRAP assays}

The antioxidant capacity (AC) was determined with the assays ABTS and FRAP, as described by Re et al. (1999) and Benzie and Strain (1996), respectively. In the first, solutions of $7 \mathrm{mM}$ ABTS and $2.6 \mathrm{mM}$ potassium persulphate were prepared and combined at 1:1 ratio. The mixture was left in darkness for $16 \mathrm{~h}$ to allow free radicals to be generated. After that, it was diluted with methanol up to absorbance of 1.1 at $734 \mathrm{~nm}$ and was named working solution (Ws). Aliquots of $20 \mu \mathrm{L}$ extract were mixed with $180 \mu \mathrm{L}$ of Ws; the mixture was left to stand for $10 \mathrm{~min}$, and absorbance was read at $734 \mathrm{~nm}$ with a Synergy ${ }^{\circledR}$ spectrophotometer. The FRAP assay used three solutions: acetate buffer at a concentration of $300 \mathrm{mM}$, a $10 \mathrm{mM}$ solution of TPTZ (2,4,6 Tri(2-pyridyl)-s triazine) dissolved in $40 \mathrm{mM} \mathrm{HCl}$, and a solution of 20 $\mathrm{mM}$ ferric chloride hexahydrate $\left(\mathrm{FeCl}_{3} \cdot 6 \mathrm{H}_{2} \mathrm{O}\right)$. A FRAP reactant was prepared with the combination of solutions at 10:1:1 proportion. A reaction was conducted for 10 min with $20 \mu \mathrm{L}$ of extract, $180 \mu \mathrm{L}$ of FRAP reactant, and $60 \mu \mathrm{L}$ of distilled water, and absorbance was measured with a Synergy ${ }^{\circledR}$ spectrophotometer at $595 \mathrm{~nm}$. A Trolox standard curve ( $\mathrm{R}^{2}$ was 0.997 and 0.999 for ABTS and FRAP assays, respectively) was prepared, and AC was expressed in mmol of Trolox equivalents per kilogram of a fresh sample $\left(\mathrm{mmol} \mathrm{kg}^{1}\right)$.

\section{Data analysis}

The experimental organization had three variation factors: temperature $\left(12\right.$ and $25^{\circ} \mathrm{C}$ ), treatments (Control,
Eo, $\mathrm{Gg}$, and $\mathrm{Gg}+\mathrm{Eo}$ ), and storage time (Table 1). An analysis of variance with means comparison routines was performed with the Tukey test, with a significance level of 0.05 . The experimental unit consisted of one fruit, and all evaluations were performed in quadruplicate.

\section{RESULTS AND DISCUSSION}

Pitaya fruits handled at $25{ }^{\circ} \mathrm{C}$ showed fungal development, which limited shelf life to six days, in agreement with the report of García-Cruz et al. (2016). Thus, the analysis was performed for the first six-day period (denoted as $6 \mathrm{~d}$ ) to evaluate the temperature effect plus an eight to 14-day period (denoted as 8-14d) to assess the storage time effect.

\section{Color attributes}

Fruits exhibited initial lightness $\left(\mathrm{L}^{*}\right)$, chroma $\left(\mathrm{C}^{*}\right)$, and hue angle $\left(\mathrm{H}^{*}\right)$ of $13.70 \%( \pm 0.77), 28.91( \pm 1.37)$, and $18.96^{\circ}\left( \pm 0.92^{\circ}\right)$ in mesocarp, and $31.39 \%( \pm 1.07 \%), 15.36$ $( \pm 0.82)$, and $50.36^{\circ}\left( \pm 2.76^{\circ}\right)$ in epicarp, respectively, which constitute typical color attributes of pitaya red variant fruits (Figure 1). There was a loss of the red tonality of flesh with refrigeration. This deteriorative feature became significant with time, since $\mathrm{H}^{*}$ was between 13.8 and $15.5^{\circ}$ at $25^{\circ} \mathrm{C}$, and between 17.4 and $19.9^{\circ}$ at $12{ }^{\circ} \mathrm{C}$ during the $6 \mathrm{~d}$ period, without significant difference, but ranged between 25.0 and 26.4 in the $8-14 \mathrm{~d}$ period at $12{ }^{\circ} \mathrm{C}$. On the other hand, the covering type did not affect the hue angle of fruits (Table 2). In epicarp, tonality ranged between 44.2 and $50.9^{\circ}$,

Table 1. Description of treatments.

\begin{tabular}{lll}
\hline Temperature & \multicolumn{1}{c}{ Treatment } & \multicolumn{1}{c}{ Description } \\
\hline $25{ }^{\circ} \mathrm{C}$ & Control & Uncoated fruit. \\
$25{ }^{\circ} \mathrm{C}$ & Eo & Thyme essential oil in emulsion with $1000 \mathrm{ppm}$ in water. \\
$25{ }^{\circ} \mathrm{C}$ & $\mathrm{Gg}$ & Emulsion composed of $1 \%$ guar gum and $15 \%$ lipid component. \\
$25{ }^{\circ} \mathrm{C}$ & $\mathrm{Gg}+\mathrm{Eo}$ & $\begin{array}{l}\text { Emulsion composed of } 1 \% \text { guar gum, } 15 \% \text { lipid phase, and } 1000 \text { ppm thyme } \\
\text { essential oil. }\end{array}$ \\
$12{ }^{\circ} \mathrm{C}$ & $\mathrm{Control}$ & Uncoated fruit. \\
$12{ }^{\circ} \mathrm{C}$ & Eo & Thyme essential oil in 1000 ppm emulsion in water. \\
$12{ }^{\circ} \mathrm{C}$ & $\mathrm{Gg}$ & Emulsion composed of $1 \%$ guar gum and $15 \%$ lipid component. \\
$12{ }^{\circ} \mathrm{C}$ & $\mathrm{Gg}+\mathrm{Eo}$ & Emulsion composed of $1 \%$ guar gum, $15 \%$ lipid phase, and 1000 ppm thyme \\
& & essential oil. \\
& & Beeswax and oleic acid at a 50:50 ratio. \\
Lipid component: &
\end{tabular}


Table 2. Comparison of means of treatments corresponding to color attributes of pitaya fruits during the first six days (subscript $6 \mathrm{~d}$ ) and between days eight and 14 (subscript 8-14d) of storage at 12 and $25^{\circ} \mathrm{C}$.

\begin{tabular}{|c|c|c|c|c|c|}
\hline \multirow{2}{*}{$\mathrm{T}_{\text {period }}$} & \multicolumn{4}{|c|}{ Treatment } & \multirow[b]{2}{*}{ HSD } \\
\hline & Control & Eo & $\mathrm{Gg}$ & $\mathrm{Gg}+\mathrm{Eo}$ & \\
\hline \multicolumn{6}{|c|}{ Lightness $\left(\mathrm{L}^{*}\right)$ in mesocarp (\%) } \\
\hline $12_{6 \mathrm{~d}}$ & $14.25(3.91) \mathrm{B} \mathrm{a}$ & $14.81(2.80) \mathrm{A} \mathrm{a}$ & 15.28 (3.39) A a & 14.35 (3.73) B a & 3.25 \\
\hline $25_{6 \mathrm{~d}}$ & $13.92(2.33) \mathrm{B} \mathrm{a}$ & $13.61(4.29) \mathrm{A} \mathrm{a}$ & $14.98(2.26) \mathrm{A} \mathrm{a}$ & $13.12(4.31) \mathrm{B} \mathrm{a}$ & 3.17 \\
\hline $12_{8-14 \mathrm{~d}}$ & $18.12(2.65) \mathrm{A} \mathrm{a}$ & $17.02(3.44) \mathrm{A} \mathrm{a}$ & $16.02(4.43) \mathrm{A} \mathrm{a}$ & $17.47(2.60) \mathrm{A} \mathrm{a}$ & 3.14 \\
\hline HSD & 2.6 & 3 & 2.98 & 3.1 & \\
\hline \multicolumn{6}{|c|}{ Lightness $\left(L^{*}\right)$ in epicarp (\%) } \\
\hline $12_{6 \mathrm{~d}}$ & $33.08(4.06) \mathrm{A} \mathrm{a}$ & $33.02(4.16) \mathrm{A} \mathrm{a}$ & 32.28 (5.37) A a & $31.88(3.48) \mathrm{B} \mathrm{a}$ & 4.04 \\
\hline $25_{6 \mathrm{~d}}$ & $34.96(4.83) \mathrm{A} \mathrm{a}$ & $33.60(3.41) \mathrm{A} \mathrm{a}$ & $33.06(2.53) \mathrm{A} \mathrm{a}$ & $31.30(5.90) \mathrm{B} \mathrm{a}$ & 4.07 \\
\hline $12_{8-14 \mathrm{~d}}$ & $32.13(4.24) \mathrm{A} \mathrm{b}$ & $34.03(2.86) \mathrm{A} \mathrm{ab}$ & 32.78 (4.12) A ab & $36.05(3.82) \mathrm{A} \mathrm{a}$ & 3.55 \\
\hline HSD & 3.76 & 3 & 3.58 & 3.88 & \\
\hline \multicolumn{6}{|c|}{ Chroma $\left(\mathrm{C}^{*}\right)$ in mesocarp } \\
\hline $12_{6 \mathrm{~d}}$ & $29.93(6.63) \mathrm{A} \mathrm{a}$ & $30.80(5.81) \mathrm{A} \mathrm{a}$ & $29.63(5.92) \mathrm{A} \mathrm{a}$ & $29.68(5.49) \mathrm{A} \mathrm{a}$ & 5.59 \\
\hline $25_{6 \mathrm{~d}}$ & $20.79(8.71) \mathrm{B}$ a & $22.69(8.18) \mathrm{B}$ a & 23.74 (10.19) A a & $19.62(9.07) \mathrm{B}$ a & 8.5 \\
\hline $12_{8-14 \mathrm{~d}}$ & $35.40(5.57) \mathrm{A} \mathrm{a}$ & $34.26(9.79) \mathrm{A} \mathrm{a}$ & $28.34(10.06) \mathrm{A} \mathrm{a}$ & $33.67(7.48) \mathrm{A} \mathrm{a}$ & 7.87 \\
\hline HSD & 6.08 & 6.97 & 7.67 & 6.42 & \\
\hline \multicolumn{6}{|c|}{ Chroma $\left(\mathrm{C}^{*}\right)$ in epicarp } \\
\hline $12_{6 \mathrm{~d}}$ & $15.71(3.82) \mathrm{AB}$ a & $14.63(2.82) \mathrm{B} \mathrm{a}$ & $15.32(3.84) \mathrm{A} \mathrm{a}$ & 16.85 (4.33) A a & 3.5 \\
\hline $25_{6 \mathrm{~d}}$ & 17.99 (5.17) A a & $18.81(5.31) \mathrm{A} \mathrm{a}$ & $17.99(3.08) \mathrm{A} \mathrm{a}$ & $17.41(4.63) \mathrm{A} \mathrm{a}$ & 4.32 \\
\hline $12_{8-14 \mathrm{~d}}$ & $14.27(3.40) \mathrm{B} \mathrm{b}$ & 15.05 (2.98) B ab & 16.95 (3.30) A ab & $17.65(2.57) \mathrm{A} \mathrm{a}$ & 2.88 \\
\hline HSD & 3.6 & 3.31 & 2.93 & 3.38 & \\
\hline \multicolumn{6}{|c|}{ Hue angle $\left(\mathrm{H}^{*}\right)$ in mesocarp (degrees) } \\
\hline $12_{6 \mathrm{~d}}$ & $18.19(7.46) \mathrm{B}$ a & 19.87 (8.65) B a & 18.06 (6.19) B a & 17.49 (5.59) B a & 15.73 \\
\hline $25_{6 \mathrm{~d}}$ & $13.80(6.46) \mathrm{B}$ a & $16.76(8.30) \mathrm{B}$ a & $15.51(8.75) \mathrm{B}$ a & $14.27(6.03) \mathrm{B}$ a & 6.99 \\
\hline $12_{8-14 \mathrm{~d}}$ & $25.08(3.97) \mathrm{A} \mathrm{a}$ & $26.39(4.03) \mathrm{A} \mathrm{a}$ & $24.66(5.85) \mathrm{A} \mathrm{a}$ & $25.83(3.32) \mathrm{A} \mathrm{a}$ & 4.1 \\
\hline HSD & 4.87 & 6.2703 & 6.04 & 4.39 & \\
\hline \multicolumn{6}{|c|}{ Hue angle $\left(\mathrm{H}^{*}\right)$ in epicarp (degrees) } \\
\hline $12_{6 \mathrm{~d}}$ & $46.30(8.60) \mathrm{A} \mathrm{a}$ & $48.52(14.91) \mathrm{A} \mathrm{a}$ & $50.80(6.70) \mathrm{A} \mathrm{a}$ & $49.50(12.87) \mathrm{A} \mathrm{a}$ & 10.52 \\
\hline $25_{6 \mathrm{~d}}$ & $44.33(8.63) \mathrm{A} \mathrm{a}$ & $44.20(9.36) \mathrm{A} \mathrm{a}$ & 44.39 (10.58) A a & $50.91(13.35) \mathrm{A} \mathrm{a}$ & 9.96 \\
\hline $12_{8-14 \mathrm{~d}}$ & $42.74(9.07) \mathrm{A} \mathrm{b}$ & $48.42(9.01) \mathrm{A} \mathrm{ab}$ & 47.03 (11.94) A ab & $55.32(11.84) \mathrm{A} \mathrm{a}$ & 9.87 \\
\hline HSD & 7.52 & 9.82 & 8.56 & 10.88 & \\
\hline
\end{tabular}

HSD: Honest significant difference (Tukey, $\alpha=0.05$ ). Different capital letters indicate a significant difference between the values of a column. Different lowercase letters indicate a significant difference between values of a row. Values between parentheses are standard deviation. Treatments: Eo, thyme essential oil emulsion at 1000 ppm; Gg, emulsion with 1\% guar gum and 15\% lipid phase; Gg+Eo, emulsion with 1\% guar gum, 15\% lipid phase, and 1000 ppm thyme essential oil.

which locate around the middle region between red and yellow absolute tones (Sant'Anna et al. 2013). In contrast to the flesh, $\mathrm{H}^{*}$ of epicarp was not affected by temperature or treatment applied during the $6 \mathrm{~d}$ period but increased $29.4 \%$ relative to Control in the $8-14 \mathrm{~d}$ period. Lightness $\left(\mathrm{L}^{*}\right)$ also tended to increase under refrigeration, but changes became significant with time only in Control and Gg+Eo treatments. Although the modification was less than 4.35 and $4.76 \%$ in pulp and epicarp, respectively, it was considered without practical importance. $L^{*}$ varied between 13.9 and 18.2 in pulp and between 31.8 and $36.0 \%$ in epicarp and, even though Gg+Eo caused higher values during the 8-14d period, the modification was small. Regarding chroma, 
the refrigeration caused a significant increment in the pulp, but the storage time and the coating applied did not affect such attribute. Values were between 19.6 and 23.8 at $25{ }^{\circ} \mathrm{C}$, between 29.6 and 30.8 during the first $6 \mathrm{~d}$ at $12{ }^{\circ} \mathrm{C}$, and between 28.3 and 35.4 in the $8-14 \mathrm{~d}$ period at $12{ }^{\circ} \mathrm{C}$. None of the variation factors affected the epicarp significantly, and values ranged between 14.2 and 18.8 (Table 2).

\section{Cumulative weight loss}

Fruits of the Control treatment tended to have more significant weight loss at the highest thermal condition. However, during the first $6 \mathrm{~d}$, the contrast was not significant in relation to the refrigerated handling and went from 2.5 to $3.9 \%$ on average (Table 3). Weight loss occurs mainly due to transpiration induced by a vapor pressure deficit at the external environment. As temperature increases, the relative humidity of the surrounding air decreases, which induces greater transport of water vapor from the interior of fruits (Hübert and Lang 2012).

Given its continuous nature, during the $8-14 \mathrm{~d}$ period at $12{ }^{\circ} \mathrm{C}$ there was an accumulated average value of $9.7 \%$, which was significantly higher than in the $6 \mathrm{~d}$ period. The treatment with essential oil (Eo) caused behavior with similar values to those of the Control treatment, which indicated that the water vapor permeability of the fruit epicarp did not change. However, weight loss was significantly reduced to less than half of that accumulated in Control with treatments based on guar gum (Gg and $\mathrm{Gg}+\mathrm{Eo})$, due to the presence of beeswax and oleic acid in the applied emulsion, which reduced the water vapor permeability of the outer layer of

Table 3. Comparison of means of treatments corresponding to cumulative weight loss, appearance, epicarp firmness, and pulp firmness in pitaya fruits during the first six days (subscript 6d) and between days eight and 14 (subscript $8-14 \mathrm{~d}$ ) of storage at 12 and $25^{\circ} \mathrm{C}$.

\begin{tabular}{|c|c|c|c|c|c|}
\hline \multirow{2}{*}{$\mathrm{T}_{\text {period }}$} & \multicolumn{4}{|c|}{ Treatment } & \multirow[b]{2}{*}{ HSD } \\
\hline & Control & Eo & $\mathrm{Gg}$ & $\mathrm{Gg}+\mathrm{Eo}$ & \\
\hline \multicolumn{6}{|c|}{ Cumulative weight loss (\%) } \\
\hline $12_{6 \mathrm{~d}}$ & 2.49 (1.98) B ab & 2.98 (2.35) B a & $1.14(0.94) \mathrm{B} b$ & $1.25(0.95) \mathrm{A} \mathrm{b}$ & 1.57 \\
\hline $25_{6 \mathrm{~d}}$ & $3.90(3.10) \mathrm{B} \mathrm{a}$ & $4.35(3.74) \mathrm{B}$ a & $3.18(2.88) \mathrm{A} \mathrm{a}$ & 3.98 (3.44) B a & 3.09 \\
\hline $12_{8-14 \mathrm{~d}}$ & $9.71(2.25) \mathrm{A} \mathrm{a}$ & $10.16(3.08) \mathrm{A} \mathrm{a}$ & $4.73(1.08) \mathrm{A} \mathrm{b}$ & $4.16(1.25) \mathrm{B} \mathrm{b}$ & 1.94 \\
\hline HSD & 2.13 & 2.66 & 1.59 & 1.87 & \\
\hline \multicolumn{6}{|c|}{ Appearance } \\
\hline $12_{6 \mathrm{~d}}$ & $4.00(0.84) \mathrm{A} \mathrm{bc}$ & 3.38 (1.13) A c & $4.69(0.38) \mathrm{A} \mathrm{a}$ & $4.31(0.55) \mathrm{A} \mathrm{ab}$ & 0.64 \\
\hline $25_{6 \mathrm{~d}}$ & $3.75(0.89) \mathrm{AB}$ a & 3.38 (1.30) A a & $3.69(1.07) \mathrm{B} \mathrm{a}$ & $3.50(1.06) \mathrm{B} \mathrm{a}$ & 0.59 \\
\hline $12_{8-14 \mathrm{~d}}$ & $3.06(0.52) \mathrm{B}$ ab & $2.94(0.52) \mathrm{B} \mathrm{b}$ & $3.94(0.77) \mathrm{B}$ a & $3.50(0.20) \mathrm{B}$ ab & 0.70 \\
\hline HSD & 0.91 & 0.40 & 0.53 & 0.62 & \\
\hline \multicolumn{6}{|c|}{$\underline{\text { Pulp firmness }(\mathrm{N})}$} \\
\hline $12_{6 \mathrm{~d}}$ & $1.67(0.40) \mathrm{A} \mathrm{a}$ & $1.70(0.28) \mathrm{A} \mathrm{a}$ & $1.79(0.39) \mathrm{A} \mathrm{a}$ & $1.79(0.17) \mathrm{A} \mathrm{a}$ & 0.30 \\
\hline $25_{6 \mathrm{~d}}$ & $1.28(0.49) \mathrm{B} \mathrm{a}$ & $1.25(0.46) \mathrm{B} \mathrm{a}$ & $1.11(0.48) \mathrm{B} \mathrm{a}$ & $1.39(0.60) \mathrm{B} \mathrm{a}$ & 0.48 \\
\hline $12_{8-14 \mathrm{~d}}$ & $1.40(0.23) \mathrm{AB} a b$ & $1.35(0.22) \mathrm{B} \mathrm{b}$ & $1.58(0.19) \mathrm{A} \mathrm{a}$ & $1.42(0.14) \mathrm{B}$ ab & 0.19 \\
\hline HSD & 0.34 & 0.29 & 0.32 & 0.32 & \\
\hline \multicolumn{6}{|c|}{ Epicarp firmness (N) } \\
\hline $12_{6 \mathrm{~d}}$ & $2.36(0.70) \mathrm{A} \mathrm{ab}$ & $2.74(0.80) \mathrm{A} \mathrm{a}$ & $2.33(0.62) \mathrm{A} \mathrm{ab}$ & $2.05(0.41) \mathrm{A} \mathrm{b}$ & 0.61 \\
\hline $25_{6 \mathrm{~d}}$ & $1.50(0.63) \mathrm{B}$ a & $1.62(0.53) \mathrm{B}$ a & $1.33(0.59) \mathrm{B} \mathrm{a}$ & $1.69(0.80) \mathrm{A} \mathrm{a}$ & 0.67 \\
\hline $12_{8-14 \mathrm{~d}}$ & $1.96(0.64) \mathrm{AB} a b$ & $2.34(0.48) \mathrm{AB}$ a & $1.93(0.65) \mathrm{A} \mathrm{ab}$ & $1.81(0.40) \mathrm{A} \mathrm{b}$ & 0.52 \\
\hline HSD & 0.56 & 0.61 & 0.53 & 0.49 & \\
\hline
\end{tabular}

HSD: Honest significant difference (Tukey, $\alpha=0.05$ ). Different capital letters indicate a significant difference between the values of a column. Different lowercase letters indicate a significant difference between values of a row. Values between parentheses are standard deviation. Treatments: Eo, thyme essential oil emulsion at 1,000 ppm; Gg, emulsion with 1\% guar gum and 15\% lipid phase; Gg+Eo, emulsion with 1\% guar gum, 15\% lipid phase, and 1,000 ppm thyme essential oil. 
fruits. In the end, Gg+Eo treatments allowed weight loss to be less than $6 \%$, which contrasted with the 10 and $11 \%$ obtained in Control and Eo treatments. Shirai et al. (2016) found similar behavior in pitaya fruits with chitosan, hydroxymethylpropyl cellulose, and neem essential oil coatings and stored at $10{ }^{\circ} \mathrm{C}$ and $80 \% \mathrm{Rh}$. In prickly pear (Opuntia albicarpa L.; Cactaceae) fruits, weight loss between 5 and $7 \%$ was found using chitosan and candelilla wax (Valle-Ortiz et al. 2019).

\section{Appearance}

The initial appearance was rated with a value of 5 , but this decreased over time and was affected by both thermal condition and treatments applied (Table 3). During the $6 \mathrm{~d}$ period, the appearance was between 3.75 and 4.00 in Control and equal to 3.38 in Eo fruits, with no difference between temperatures. Coatings did not cause a beneficial effect at $25^{\circ} \mathrm{C}$, but they did at $12{ }^{\circ} \mathrm{C}$, where $\mathrm{Gg}$ and $\mathrm{Gg}+$ Eo caused better appearance than the other two. The contrast persisted during the 8-14d period with values of 3.94 and 3.50, respectively, which indicated a favorable effect on shelf-life extension. Most of the fruits stored at $25^{\circ} \mathrm{C}$ presented fungal contamination on the sixth day of sampling, particularly with Alternaria alternata (Fr.) Keissl, Penicillium italicum Raper \& Thom, and Rhizopus stolonifer (Ehrenb.:Fr.) Vuill. (data not shown), which caused panelists to give low ratings for appearance; however, after epicarp removal, the pulp was observed undamaged, so fruits could be destinated to the extraction of several compounds, such as betalains, as showed by Vargas-Campos et al. (2018).

\section{Firmness}

Epicarp and mesocarp firmness was $2.84( \pm 0.14)$ and $1.86( \pm 0.07) \mathrm{N}$, respectively, at the beginning. From there on, firmness diminished in fruits handled at 25 ${ }^{\circ} \mathrm{C}$, and values were within $1.11-1.39$ and $1.33-1.69 \mathrm{~N}$ in mesocarp and epicarp, respectively, with no difference among treatments during the $6 \mathrm{~d}$ period (Table 3 ). The refrigeration delayed softening, since firmness in epicarp and mesocarp was in the range of 1.67-1.79 and 2.05-2.74 N, respectively, during the same $6 \mathrm{~d}$ period. Firmness loss continued along time, and values ranged between 1.35-1.58 and 1.81-2.34 $\mathrm{N}$ in mesocarp and epicarp during the $8-14 \mathrm{~d}$ period at $12{ }^{\circ} \mathrm{C}$. Fruit softening occurs mainly during the ripening process, but it continues during senescence, derived from the degradation of cell wall polymers and the dissolution of the middle layer at tissue level (Valero and Serrano 2010). In the case of pulp, Gg treatment allowed fruits to have the highest firmness during the $8-14 \mathrm{~d}$ period, which indicated a beneficial effect of using coatings based on guar gum-beeswax-oleic acid, because they modified the gas exchange capacity of fruits and favored shelf-life extension (Torres-León et al. 2018). However, in epicarp, the highest values occurred in Control and Eo treatments, which may have been associated with hardening derived from dehydration, since fruits showed the highest physiological weight loss.

\section{Chemical variables}

Total soluble solids (TSS), $\mathrm{pH}$, and titratable acidity (TA) had initial values of $0.094 \%( \pm 0.003 \%), 5.48( \pm 0.04)$, and $12.68 \%( \pm 0.21 \%)$, respectively. These properties were not significantly affected by temperature and storage time or treatment applied. Although some variations took place (Table 4), they were little and may correspond to normal variability among fruits. Due to the nonclimacteric character, pitaya fruits do not continue ripening after harvest but rather lead to senescence, so TSS, pH, and TA remained constant throughout storage. Pitaya can be classified as a low acidity fruit, with a TSS/TA ratio of 117.8. The pitahaya fruit contains similar TSS but higher TA, with a TSS/TA ratio of 17.9 (Liu et al. 2019), so pitaya fruit is perceived with greater sweetness than pitahaya. The main components of soluble solids in fruits are glucose, fructose, and sucrose (Torres et al. 2013), and their combination results in sweetness. Among organic acids, the most important in ripe fruits are malic, citric, tartaric, quinic, oxalic, fumaric, and succinic, which contribute to the overall taste of fruits (Valero and Serrano 2010). The most important sugars and organic acids of pitaya fruits have not been identified yet; however, this species belongs to the Cactaceae family, and the photosynthesis process occurs through the Crassulaceae acid metabolism (CAM), where malic acid is an intermediary for the production of sugars (Andrade et al. 2007), thus the quantification of titratable acidity was expressed as a function of malic acid. 
Table 4. Comparison of means of treatments corresponding to titratable acidity, $\mathrm{pH}$, and total soluble solids in pitaya fruits during the first six days (subscript 6d) and between days eight and 14 (subscript 8-14d) of storage at 12 and $25^{\circ} \mathrm{C}$.

\begin{tabular}{|c|c|c|c|c|c|}
\hline \multirow{2}{*}{$\mathrm{T}_{\text {period }}$} & \multicolumn{4}{|c|}{ Treatment } & \multirow[b]{2}{*}{ HSD } \\
\hline & Control & Eo & $\mathrm{Gg}$ & $\mathrm{Gg}+\mathrm{Eo}$ & \\
\hline \multicolumn{6}{|c|}{ Titratable acidity (\%) } \\
\hline $12_{6 \mathrm{~d}}$ & $0.11(0.03) \mathrm{A} \mathrm{a}$ & $0.09(0.02) \mathrm{A} \mathrm{b}$ & $0.10(0.02) \mathrm{A} \mathrm{ab}$ & $0.09(0.02) \mathrm{A} \mathrm{b}$ & 0.020 \\
\hline $25_{6 \mathrm{~d}}$ & $0.07(0.03) \mathrm{B} \mathrm{a}$ & $0.09(0.02) \mathrm{A} \mathrm{a}$ & $0.08(0.03) \mathrm{B} \mathrm{a}$ & $0.08(0.02) \mathrm{A} \mathrm{a}$ & 0.023 \\
\hline $12_{8-14 \mathrm{~d}}$ & $0.08(0.03) \mathrm{B}$ a & $0.09(0.02) \mathrm{A} \mathrm{a}$ & $0.09(0.02) \mathrm{AB} a$ & $0.09(0.01) \mathrm{A} \mathrm{a}$ & 0.020 \\
\hline HSD & 0.023 & 0.017 & 0.019 & 0.017 & \\
\hline \multicolumn{6}{|c|}{$\mathrm{pH}$} \\
\hline $12_{6 \mathrm{~d}}$ & $5.60(0.41) \mathrm{A} \mathrm{a}$ & $5.64(0.28) \mathrm{AB} a$ & $5.47(0.36) \mathrm{A} \mathrm{a}$ & $5.51(0.28) \mathrm{A} \mathrm{a}$ & 0.316 \\
\hline $25_{6 \mathrm{~d}}$ & $5.65(0.40) \mathrm{A} \mathrm{a}$ & $5.73(0.38) \mathrm{A} \mathrm{a}$ & 5.68 (0.39) A a & $5.67(0.38) \mathrm{A} \mathrm{a}$ & 0.362 \\
\hline $12_{8-14 \mathrm{~d}}$ & 5.38 (0.37) A a & $5.42(0.35) \mathrm{B}$ a & $5.60(0.40) \mathrm{A} \mathrm{a}$ & $5.44(0.33) \mathrm{A} \mathrm{a}$ & 0.339 \\
\hline HSD & 0.338 & 0.292 & 0.329 & 0.285 & \\
\hline \multicolumn{6}{|c|}{$\underline{\text { Total soluble solids (\%) }}$} \\
\hline $12_{6 \mathrm{~d}}$ & $10.96(1.59) \mathrm{A} \mathrm{b}$ & $12.66(1.48) \mathrm{A} \mathrm{a}$ & $11.58(1.64) \mathrm{A} \mathrm{ab}$ & $11.88(1.45) \mathrm{A} \mathrm{ab}$ & 1.44 \\
\hline $25_{6 \mathrm{~d}}$ & $11.63(1.55) \mathrm{A} \mathrm{a}$ & $10.59(1.68) \mathrm{B}$ a & $11.28(1.60) \mathrm{A} \mathrm{a}$ & 11.69 (1.71) A a & 1.53 \\
\hline $12_{8-14 \mathrm{~d}}$ & $11.23(1.02) \mathrm{A} \mathrm{a}$ & $10.72(1.15) \mathrm{B}$ ab & $11.35(1.20) \mathrm{A} \mathrm{a}$ & $10.05(0.91) \mathrm{B} \mathrm{b}$ & 1.01 \\
\hline HSD & 1.21 & 1.25 & 1.28 & 1.20 & \\
\hline
\end{tabular}

HSD: Honest significant difference (Tukey, $\alpha=0.05$ ). Different capital letters indicate a significant difference between the values of a column. Different lowercase letters indicate a significant difference between values of a row. Values between parentheses are standard deviation. Treatments: Eo, thyme essential oil emulsion at 1,000 ppm; Gg, emulsion with $1 \%$ guar gum and 15\% lipid phase; Gg+Eo, emulsion with $1 \%$ guar gum, 15\% lipid phase, and 1,000 ppm thyme essential oil.

\section{Bioactive compounds}

The initial content of total soluble phenols (TSP) varied between 340 and $404 \mathrm{mg} \mathrm{kg}^{-1}$, less than that reported by García-Cruz et al. (2016), which suggested that the chemical composition of pitaya fruits can vary significantly. According to Parra et al. (2012), the traditional classification of these fruits by color can be subdivided, explaining variations relative to previously published data. The use of refrigeration caused a reduction in TSP, but the effect was not significant until the 8 -14d period in the Control treatment (Table 5).

Cold storage can alter the phenolic composition in fruits and vegetables. In some cases, new components are synthesized, and the concentration increases; in others, the content decreases due to the metabolism of fruits (Tomás-Barberan et al. 2000). Fruits of the Eo treatment behaved similarly to those of Control, indicating that the essential oil did not alter any characteristic of fruits. In treatments $\mathrm{Gg}$ and $\mathrm{Gg}+\mathrm{Eo}$, a reduction of TSP was observed, and this occurred since the first $6 \mathrm{~d}$ period. However, the content was not modified with storage time, and values during the $8-14 \mathrm{~d}$ period were sta- tistically similar. Likewise, differences between values of this last period and those of handling at $25{ }^{\circ} \mathrm{C}$ were less than $3.5 \%$. In fruits of garambullo (Myrtillocactus geometrizans (Mart. ex. Pfeiff.); Cactaceae) TSP decreased up to $70 \%$ during $15 \mathrm{~d}$ at $5{ }^{\circ} \mathrm{C}$ (Correa-Betanzo et al. 2011), which was almost three times as high as that of pitaya fruit. Similarly, TSP can diminish up to $75 \%$ in pitahaya along with a $16 \mathrm{~d}$ storage at $20^{\circ} \mathrm{C}$ (Zahid et al. 2013).

The red color in the flesh of pitaya fruits is caused by betalains (Vargas-Campos et al. 2018), whose content varied between 303 and $438 \mathrm{mg} \mathrm{kg}^{-1}$ initially, coinciding with the value $424.6 \mathrm{mg} \mathrm{kg}^{-1}$ reported by García-Cruz et al. (2016). The Control treatment material maintained betalains content without significant variation along with storage, which was also reported by García-Cruz et al. (2016) and Rosas-Benítez et al. (2016). In the case of fruits treated with coatings, some variations occurred along with storage, but without any trend, and, at the end of the $8-14 \mathrm{~d}$ period, the content was similar to that of Control (Table 5). The present work focused on the red pitaya variant. The betaxanthins content was slightly higher than that of betacyanins at 1.1:1.0 ratio, which differed with the 3.2:1.0 ratios found in other 
red pitaya variants (García-Cruz et al. 2017). Likewise, in other cacti fruit, such as pitahaya, garambullo, and prickly pear, ratios of 1.0:2.9, 1.0:2.3, and 1.0:1.9 have been reported, respectively (López-Palestina et al. 2018; Ortega-Hernández et al. 2018; Wu et al. 2019), because the main pigments in these materials have been betacyanins. Other studies on S. pruinosus have identified betalains such as gomfrenin I, isogomfrenin I, 2-descarboxy-betanin, phylloactin, isofilocactin, 6'O-malonyl-2-descarboxy-betanin, 6'O-malonyl-2descarboxi-isobetanin, indicaxanthin, isoindicaxanthin, and vulgaxanthin IV (García-Cruz et al. 2017).

\section{Antioxidant capacity}

The ABTS assay reported antioxidant activity (AC) between $3.40-3.80 \mathrm{mmol} \mathrm{kg}^{-1}$ at the beginning and
$3.67-4.20 \mathrm{mmol} \mathrm{kg}^{-1}$ at the end of the storage time, although without significant contrast. There was no significant effect caused by temperature and by the treatment applied. At the end of the $8-14 \mathrm{~d}$ period, there were no differences between treatments and, although AC showed high or low values on some days, there was not a clear trend. The FRAP assay indicated that AC varied within 1.05 and $1.72 \mathrm{mmol} \mathrm{kg}{ }^{-1}$ initially. No effect was observed due to temperature variation, storage time, or coating applied, since values at the end of the $8-14 \mathrm{~d}$ period were between 1.24 and 1.33 $\mathrm{mg} \mathrm{kg}^{-1}$ (Table 5). Although betalains are compounds with hig $\mathrm{h}$ nutraceutical potential, the $\mathrm{AC}$ has been attributed more to phenolic compounds (García-Cruz et al. 2016; Rosas-Benítez et al. 2016). The values of AC measured by ABTS were different to those obtained

Table 5. Comparison of means of treatments corresponding to the content of total soluble phenols, the content of total betalains, and antioxidant activity determined with the ABTS and FRAP assays in pitaya fruits during the first six days (subscript $6 \mathrm{~d}$ ) and between days eight and 14 (subscript 8-14d) of storage at 12 and $25^{\circ} \mathrm{C}$.

\begin{tabular}{|c|c|c|c|c|c|}
\hline \multirow{2}{*}{$\mathrm{T}_{\text {period }}$} & \multicolumn{4}{|c|}{ Treatment } & \multirow[b]{2}{*}{ HSD } \\
\hline & Control & Eo & $\mathrm{Gg}$ & $\mathrm{Gg}+\mathrm{Eo}$ & \\
\hline \multicolumn{6}{|c|}{ Total soluble phenols ( $\mathrm{mg} \mathrm{kg}^{1}$ ) } \\
\hline $12_{6 \mathrm{~d}}$ & 328.19 (48.49) $\mathrm{AB} a b$ & 341.93 (38.20) A a & $318.05(36.84) \mathrm{A} \mathrm{ab}$ & $300.93(32.86) \mathrm{A} \mathrm{b}$ & 36.92 \\
\hline $25_{6 \mathrm{~d}}$ & $346.07(30.89) \mathrm{A} \mathrm{a}$ & $352.39(31.41) \mathrm{A} \mathrm{a}$ & $307.51(32.11) \mathrm{A} \mathrm{b}$ & 320.33 (39.93) A ab & 32.52 \\
\hline $12_{8-14 \mathrm{~d}}$ & 301.87 (53.14) B a & $319.14(50.83) \mathrm{B}$ a & $318.08(49.65) \mathrm{A} \mathrm{a}$ & $302.57(48.36) \mathrm{A} \mathrm{a}$ & 47.20 \\
\hline HSD & 38.73 & 31.05 & 34.46 & 35.02 & \\
\hline \multicolumn{6}{|c|}{$\underline{\text { Total betalains }\left(\mathrm{mg} \mathrm{kg}^{\underline{1}}\right)}$} \\
\hline $12_{6 \mathrm{~d}}$ & $332.41(49.06) \mathrm{A} \mathrm{a}$ & $359.09(44.70) \mathrm{A} \mathrm{a}$ & $340.98(44.84) \mathrm{A} \mathrm{a}$ & $334.13(36.39) \mathrm{A} \mathrm{a}$ & 41.10 \\
\hline $25_{6 \mathrm{~d}}$ & 347.55 (23.95) A a & 351.18 (30.08) $\mathrm{AB}$ a & $324.81(25.42) \mathrm{AB}$ a & 324.88 (29.47) A a & 25.36 \\
\hline $12_{8-14 \mathrm{~d}}$ & $326.03(49.43) \mathrm{A} \mathrm{a}$ & 320.50 (43.55) B a & $308.62(36.80) \mathrm{B}$ a & $318.32(21.54) \mathrm{A} \mathrm{a}$ & 36.66 \\
\hline HSD & 36.44 & 34.11 & 31.33 & 25.50 & \\
\hline \multicolumn{6}{|c|}{$\underline{\text { Antioxidant capacity (ABTS, mmol kg }}$ ) } \\
\hline $12_{6 \mathrm{~d}}$ & $3.92(0.29) \mathrm{A} \mathrm{a}$ & $3.90(0.26) \mathrm{A} \mathrm{a}$ & $3.96(0.23) \mathrm{A} \mathrm{a}$ & $3.94(0.26) \mathrm{A} \mathrm{a}$ & 0.243 \\
\hline $25_{6 \mathrm{~d}}$ & $3.90(0.23) \mathrm{A} \mathrm{a}$ & $3.90(0.32) \mathrm{A} \mathrm{a}$ & $3.89(0.22) \mathrm{A} \mathrm{a}$ & $3.92(0.20) \mathrm{A} \mathrm{a}$ & 0.228 \\
\hline $12_{8-14 \mathrm{~d}}$ & $3.94(0.15) \mathrm{A} \mathrm{a}$ & $3.93(0.11) \mathrm{A} \mathrm{a}$ & $3.98(0.26) \mathrm{A} \mathrm{a}$ & $3.89(0.15) \mathrm{A} \mathrm{a}$ & 0.163 \\
\hline HSD & 0.195 & 0.209 & 0.204 & 0.177 & \\
\hline \multicolumn{6}{|c|}{ Antioxidant capacity (FRAP, mmol kg1) } \\
\hline $12_{6 \mathrm{~d}}$ & $1.32(0.13) \mathrm{A} \mathrm{a}$ & $1.37(0.19) \mathrm{A} \mathrm{a}$ & $1.24(0.14) \mathrm{A} \mathrm{a}$ & $1.27(0.19) \mathrm{A} \mathrm{a}$ & 0.154 \\
\hline $25_{6 \mathrm{~d}}$ & $1.31(0.16) \mathrm{A} \mathrm{a}$ & $1.29(0.13) \mathrm{A} \mathrm{a}$ & 1.17 (0.16) A a & $1.26(0.19) \mathrm{A} \mathrm{a}$ & 0.152 \\
\hline $12_{8-14 \mathrm{~d}}$ & $1.33(0.24) \mathrm{A} \mathrm{a}$ & $1.41(0.22) \mathrm{A} \mathrm{a}$ & $1.27(0.22) \mathrm{A} \mathrm{a}$ & $1.24(0.19) \mathrm{A} \mathrm{a}$ & 0.204 \\
\hline HSD & 0.156 & 0.157 & 0.153 & 0.164 & \\
\hline
\end{tabular}

HSD: Honest significant difference (Tukey, $\alpha=0.05$ ). Different capital letters indicate a significant difference between the values of a column. Different lowercase letters indicate a significant difference between values of a row. Values between parentheses are standard deviation. Treatments: Eo, thyme essential oil emulsion at 1,000 ppm; Gg, emulsion with $1 \%$ guar gum and $15 \%$ lipid phase; Gg+Eo, emulsion with $1 \%$ guar gum, $15 \%$ lipid phase, and 1,000 ppm thyme essential oil. 
with the FRAP procedure, due to the ABTS method measures the capacity of a compound to capture the radical $\mathrm{ABTS}^{*+}$ (Re et al. 1999), while FRAP evaluates the reducing capacity of $\mathrm{Fe}^{3+}$ to form $\mathrm{Fe}^{2+}$ (Benzie and Strain 1996).

\section{Conclusions}

Temperature was the main conservation factor of pitaya fruits since the physical, chemical, and phytochemical characteristics remained unchanged for eight more days at $12{ }^{\circ} \mathrm{C}$ relative to the $25{ }^{\circ} \mathrm{C}$ condition. Coatings based on guar gum, beeswax, and oleic acid reduced weight loss in comparison with fruits without coatings; besides, they allowed maintaining a fresh appearance in fruits without the modification of quality attributes such as color, firmness, $\mathrm{pH}$, TSS, and TA, contents of soluble phenols and betalains, or antioxidant capacity. Fruits were placed $24 \mathrm{~h}$ in refrigeration previous to the experiment. Thus, guar gum and beeswax coatings, combined with refrigeration at $12{ }^{\circ} \mathrm{C}$, achieved the extension of pitaya fruit shelf life for $15 \mathrm{~d}$ in postharvest.

\section{Acknowledgements}

Authors wish to acknowledge the financial support received from Consejo Nacional de Ciencia y Tecnología of Mexico (CONACyT). 


\section{Literature Cited}

Andrade JL, De la Barrera E, Reyes-García C, Ricalde MF, Vargas-Soto G, Cervera JC. 2007. El metabolismo ácido de las crasuláceas: diversidad, fisiología ambiental y productividad. Boletín de la Sociedad Botánica de México 81: 37-50. http://doi.org/10.17129/botsci.1764

Armella MA, Yanez-López L, Soriano J, Ramírez R. 2003. Phenology, postharvest physiology and marketing of pitaya (Stenocereus griseus, L.) as a sustainable resourse. Acta Horticulturae 598: 251-254. http://doi. org/10.17660/ActaHortic.2003.598.37

Benzie IFF, Strain JJ. 1996. The ferric reducing ability of plasma (FRAP) as a measure of "antioxidant power": The FRAP assay. Analytical Biochemistry 239: 70-76. http://doi.org/10.1006/abio.1996.0292

Casas A, Otero-Arnaiz A, Pérez-Negrón E, ValienteBanuet A. 2007. In situ management and domestication of plants in Mesoamerica. Annals of Botany 100: 1101-1115. http://doi.org/10.1093/aob/mcm126

Castellanos-Santiago E, Yahia EM. 2008. Identification and quantification of betalains from the fruits of 10 Mexican prickly pear cultivars by high-performance liquid chromatography and electrospray ionization mass spectrometry. Journal of Agricultural and Food Chemistry 56: 5758-5764. http://doi.org/10.1021/ jf800362t

Chuck-Hernández C, Parra-Saldívar R, Sandate-Flores L. 2015. Pitaya (Stenocereus spp.). In: Caballero B, Finglas PM, Toldrá F, editors. Encyclopedia of Food and Health. Oxford, Elsevier. P. 385-391.

Correa-Betanzo J, Jacob JK, Perez-Perez C, Paliyath G. 2011. Effect of a sodium caseinate edible coating on berry cactus fruit (Myrtillocactus geometrizans) phytochemicals. Food Research International 44: 1897-1904. http://doi.org/10.1016/J.FOODRES.2010.10.053

García-Cruz L, Valle-Guadarrama S, Salinas-Moreno Y, Joaquín-Cruz E. 2013. Physical, chemical, and antioxidant activity characterization of pitaya (Stenocereus pruinosus) fruits. Plant Foods for Human Nutrition 68: 403-410. http://doi.org/10.1007/s11130-013-0391-8

García-Cruz L, Valle-Guadarrama S, Salinas-Moreno Y, Luna-Morales CdelC. 2016. Postharvest quality, soluble phenols, betalains content, and antioxidant activity of Stenocereus pruinosus and Stenocereus stellatus fruit. Postharvest Biology and Technology 111: 69-76. http://doi.org/10.1016/j.postharvbio.2015.07.004
García-Cruz L, Dueñas M, Santos-Buelgas C, ValleGuadarrama S, Salinas-Moreno Y. 2017. Betalains and phenolic compounds profiling and antioxidant capacity of pitaya (Stenocereus spp.) fruit from two species (S. pruinosus and S. stellatus). Food Chemistry 234: 111-118. http://doi.org/10.1016/j.foodchem.2017.04.174

Hübert T, Lang C. 2012. Artificial fruit: Postharvest online monitoring of agricultural food by measuring humidity and temperature. International Journal of Thermophysics 33: 1606-1615. http://doi.org/10.1007/ s10765-011-1101-0

Liu R, Gao H, Chen H, Fang X, Wu W. 2019. Synergistic effect of 1-methylcyclopropene and carvacrol on preservation of red pitaya (Hylocereus polyrhizus). Food Chemistry 283: 588-595. http://doi.org/10.1016/J. FOODCHEM.2019.01.066

López-Palestina CU, Aguirre-Mancilla CL, Raya-Pérez JC, Ramírez-Pimentel JG, Gutiérrez-Tlahque J, HernándezFuentes AD. 2018. The effect of an edible coating with tomato oily extract on the physicochemical and antioxidant properties of garambullo (Myrtillocactus geometrizans) fruits. Agronomy 8: 248. http://doi.org/10.3390/ agronomy 8110248

Martínez-Mendoza AA, Franco-Mora O, Sánchez-Pale JR, Rodríguez-Núñez JR, Castañeda-Vildózola Á. 2020. Evaluación de recubrimientos comestibles a base de pectina de tejocote (Crataegus mexicana Moł. \& Sess, ex DC., Rosaceae) en la poscosecha de tihuixocote (Ximenia americana L., Olacaceae). Acta Agrícola y Pecuaria 6: E0061004. https://doi.org/10.30973/aap/2020.6.0061004

Ortega-Hernández E, Welti-Chanes J, Jacobo-Velázquez DA. 2018. Effects of UVB light, wounding stress, and storage time on the accumulation of betalains, phenolic compounds, and ascorbic acid in red prickly pear (Opuntia ficus-indica cv. Rojo Vigor). Food and Bioprocess Technology 11: 2265-2274. https://doi. org/10.1007/s11947-018-2183-5

Parra F, Blancas JJ, Casas A. 2012. Landscape management and domestication of Stenocereus pruinosus (Cactaceae) in the Tehuacán Valley: Human guided selection and gene flow. Journal of Ethnobiology and Ethnomedicine 8: 32. https://doi.org/10.1186/1746-4269-8-32

Re R, Pellegrini N, Proteggente A, Pannala A, Yang M, RiceEvans C. 1999. Antioxidant activity applying an improved ABTS radical cation decolorization assay. Free Radical Biology and Medicine 26: 1231-1237. https://doi. org/10.1016/S0891-5849(98)00315-3 
Rives-Castillo SCH, Ventura-Aguilar RI, Hernández-López M, Bautista-Baños S. 2018. Evaluación de recubrimientos biodegradables para la conservación en fresco de jitomate Kenton. Acta Agrícola y Pecuaria 4: 80-91. https://doi.org/10.30973/aap/2018.4.3/2

Rodríguez-Sánchez JA, Cruz y Victoria MT, BarragánHuerta BE. 2017. Betaxanthins and antioxidant capacity in Stenocereus pruinosus: Stability and use in food. Food Research International 91: 63-71. https://doi. org/10.1016/j.foodres.2016.11.023

Rosas-Benítez A, Trujillo-Cárdenas L, Valle-Guadarrama S, Salinas-Moreno Y, García-Cruz L. 2016. Quality attributes of pitaya (Stenocereus pruinosus) fruit handled in postharvest with and without thorns under refrigerated storage. Revista Chapingo Serie Horticultura 22: 191207. https://doi.org/10.5154/r.rchsh.2016.04.011

Sant'Anna V, Gurak PD, Marczak LDF, Tessaro IC. 2013. Tracking bioactive compounds with colour changes in foods - A review. Dyes and Pigments 98: 601-608. https://doi.org/10.1016/J.DYEPIG.2013.04.011

Shirai K, Hernandez CG, Mejía P, Blanco S, RománGuerrero A, Yañez L, Escalona-Buendía HB. 2016. Postharvest preservation of cactus fruits produced in semidesertic area of Oaxaca by biopolymer coatings. The International Journal of Interdisciplinary Social Sciences: Annual Review 11: 15-26. http://doi. org/10.18848/1833-1882/CGP/15-26

Singleton VL, Rossi JA. 1965. Colorimetry of total phenolics with phosphomolybdic-phosphotungstic acid reagents. American Journal of Enology and Viticulture 16: 144-158.

Tomás-Barberan FA, Ferreres F, Gil MI. 2000. Antioxidant phenolic metabolites from fruit and vegetables and changes during postharvest storage and processing. Studies in Natural Products Chemistry 23: 739-795. https://doi.org/10.1016/S1572-5995(00)80141-6

Torres R, Montes EJ, Pérez OA, Andrade RD. 2013. Relación del color y del estado de madurez con las propiedades fisicoquímicas de frutas tropicales. Informacion Tecnológica 24: 51-56. https://doi.org/10.4067/ S0718-07642013000300007

Torres-León C, Vicente AA, Flores-López ML, Rojas R, Serna-Cock L, Alvarez-Pérez OB, Aguilar CN. 2018. Edible films and coatings based on mango (var. Ataulfo) by-products to improve gas transfer rate of peach. LWT - Food Science \& Technology 97: 624-631. https://doi. org/10.1016/j.lwt.2018.07.057
Valero D, Serrano M. 2010. Postharvest Biology and Technology for Preserving Fruit Quality. Taylor \& Francis. Florida, USA.

Valle-Ortiz DJ, Gómez-Cruz A, Hernández-Fuentes AD, Valle-Guadarrama S. 2019. Microbial control in white cactus pear with biopolymeric coating of chitosan, candelilla wax and thyme essential oil. Revista Fitotecnia Mexicana 42: 201-207. https://doi.org/10.35196/ rfm.2019.3.201-207

Vargas-Campos L, Valle-Guadarrama S, Martínez-Bustos F, Salinas-Moreno Y, Lobato-Calleros C, Calvo-López AD. 2018. Encapsulation and pigmenting potential of betalains of pitaya (Stenocereus pruinosus) fruit. Journal of Food Science and Technology 55: 2436-2445. https:// doi.org/10.1007/s13197-018-3161-7

Wu Y, Xu J, He Y, Shi M, Han X, Li W, Zhang X, Wen X. 2019. Metabolic profiling of pitaya (Hylocereus polyrhizus) during fruit development and maturation. Molecules 24: 1114. https://doi.org/10.3390/molecules24061114

Zahid N, Ali A, Siddiqui Y, Maqbool M. 2013. Efficacy of ethanolic extract of propolis in maintaining postharvest quality of dragon fruit during storage. Postharvest Biology and Technology 79: 69-72. https://doi. org/10.1016/j.postharvbio.2013.01.003 